Article

\title{
Assessing the Water-Resources Potential of Istanbul by Using a Soil and Water Assessment Tool (SWAT) Hydrological Model
}

\author{
Gokhan Cuceloglu ${ }^{1,2, *}$ (D), Karim C. Abbaspour ${ }^{2}$ and Izzet Ozturk ${ }^{1}$ \\ 1 Environmental Engineering Department, Istanbul Technical University, 34469 Maslak, Istanbul, Turkey; \\ ozturkiz@itu.edu.tr \\ 2 EAWAG, Swiss Federal Institute of Aquatic Science and Technology, 8600 Dübendorf, Switzerland; \\ karim.abbaspour@eawag.ch \\ * Correspondence: cuceloglu@itu.edu.tr; Tel.: +90-212-285-3776
}

Received: 15 September 2017; Accepted: 20 October 2017; Published: 24 October 2017

\begin{abstract}
Uncertainties due to climate change and population growth have created a critical situation for many megacities. Investigating spatio-temporal variability of water resources is, therefore, a critical initial step for water-resource management. This paper is a first study on the evaluation of water-budget components of water resources in Istanbul using a high-resolution hydrological model. In this work, the water resources of Istanbul and surrounding watersheds were modeled using the Soil and Water Assessment Tool (SWAT), which is a continuous-time, semi-distributed, process-based model. The SWAT-CUP program was used for calibration/validation of the model with uncertainty analysis using the SUFI-2 algorithm over the period 1977-2013 at 25 gauge stations. The results reveal that the annual blue-water potential of Istanbul is 3.5 billion $\mathrm{m}^{3}$, whereas the green-water flow and storage are 2.9 billion $\mathrm{m}^{3}$ and 0.7 billion $\mathrm{m}^{3}$, respectively. Watersheds located on the Asian side of the Istanbul megacity yield more blue-water resources compared to the European side, and constitute $75 \%$ of the total potential water resources. The model highlights the water potential of the city under current circumstances and gives an insight into its spatial distribution over the region. This study provides a strong basis for forthcoming studies concerning better water-resources management practices, climate change and water-quality studies, as well as other socio-economic scenario analyses in the region.
\end{abstract}

Keywords: hydrological modeling; SWAT; SWAT-CUP; water-resources modeling; water availability; water potential; Istanbul

\section{Introduction}

As demand for water increases across the world, the availability of freshwater in many regions is likely to decrease due to population growth, industrialization, land use and climate change. Climate change due to the greenhouse effect plays a vital role in the availability of freshwater and is just one of the pressures facing water resources today. Nearly all of the climate change projections indicate substantial decreases in water availability in the Mediterranean region in the future [1-5]. On the other hand, rapid population increase, urbanization, and industrialization in this region have had a significant effect on the regional hydrological cycle. As the population increases, the provision of clean water in the megacities of developing countries becomes increasingly more complex [6]. Continuing urbanization poses a major challenge to providing adequate water services to the metropolis [7].

Quantifying the water resources of a megacity is essential for providing the strategic information needed for long-term planning of the city's water security. Conventional water-resource planning and 
management have mostly been based on "blue-water" resources, which serve the needs of engineers who are responsible for coping with infrastructure projects for water supply [8]. Blue water is generally defined as "the sum of river discharge and deep groundwater recharge". "Green water", however, is differentiated by Falkenmark and Rockström [8] between green-water resources and green-water flows. According to their definition, "green-water resource is the moisture in the soil". This is the renewable part that can potentially generate economic returns and the source of rainfed agriculture. Green-water flow, however, is the actual evaporation (the non-productive part) and the actual transpiration (the productive part), commonly referred to together as the actual evapotranspiration [9]. Thus, it is vital to evaluate the blue- and green-water potential for human activities. This water paradigm is successfully used to evaluate water resources and its availability throughout the world using Soil and Water Assessment Tool (SWAT) models at continent, country, or basin scales [9-15].

In 2016, Istanbul had a population of 15 million within the city proper. It is not only the most populous city in Turkey, but one of the biggest conurbations in the world whose population is still increasing due to a high level of migration by approximately 250,000 people every year [16] from all over the country. The annual population growth rate is $2.8 \%$, which is almost twice the overall rate of Turkey [17]. Furthermore, due to the Syrian war, Istanbul hosts 600,000 Syrian refugees per year. Demand for water in the city, which is supplied mainly (about 98\%) from surface water resources in 15 watersheds, is about 3 million $\mathrm{m}^{3}$ day $^{-1}$, including domestic and industrial consumption as well as non-reserve water (NRW) or water losses. Water supply has always been a great challenge throughout the history of Istanbul, from ancient times to the present.

One of the most comprehensive studies on İstanbul's water resources is reported by the Istanbul Master Plan Consortium (IMC) [18] for the planning of water-supply, wastewater and stormwater investments in the Istanbul Metropolitan Area. Akkoyunlu et al. [19], Eroglu et al. [20], Yuksel et al. [21], Altinbilek [22], Saatci [23], Ozturk and Altay [24] and van Leeuwen and Sjerps [17], reported on current water-management strategies, challenges in water supply, and future directions regarding water administration in the city mostly based on the IMC report. Few studies can be found on water budgets of the watersheds of Istanbul covering individual sub-basins [25,26]. Kara and Yucel [27] and the Istanbul Water and Sewerage Administration (ISKI) [28] used trend analysis to study the impact of climate change on extreme flows in Istanbul. They concluded that a significant impact could be expected on the frequency and amount of hydrological extremes such as floods and droughts. Cuceloglu and Ozturk [29,30] quantified the water-budget components of major freshwater resources of Istanbul by using the SWAT model. Rouholahnejad et al. [12] studied the water resources of the European part of Turkey in the context of the Black Sea Basin.

To the best of our knowledge, no systematic modeling work has been done on the water resources of Istanbul to quantify both the potential of all watersheds in supplying potable water, and to quantify water availability in terms of various components of the water budget with a high resolution. This study has been conducted to fill this gap, and will be the first study covering all of the current and planned catchment areas of Istanbul. Also, the hydrological model built in this study will serve as the base model for forthcoming studies to evaluate climate change impacts and water quality in order to guide engineers, experts, as well as policy-makers and authorities in the region.

The overall objectives of the current study are: (1) to build a high-resolution hydrological model for all the watersheds (existing and planned) that could supply drinking water; (2) to calibrate and validate the model and perform sensitivity and uncertainty tests upon its outputs; and (3) to reveal the current water budget in terms of blue- and green-water resources. For this purpose, we used SWAT to build the hydrological model and SWAT-CUP to calibrate and validate the model. 


\section{Materials and Methods}

\subsection{Study Area}

Istanbul is located in the north-west of Turkey within the Marmara region, intersecting two continents, namely Asia and Europe. The surface area of Istanbul is $5540 \mathrm{~km}^{2}$. Forest territories cover $44 \%$ of the city, mainly in the northern part. A large majority of the settlements (with a $2700 \mathrm{capita} / \mathrm{km}^{2}$ population density) are concentrated on the south coast of the city (Figure 1). The city has a transitional climate, impacted by the Black Sea to the north, and the Marmara Sea and the Aegean Sea to the south. The northern parts of the city, where forested areas mostly lie, is affected by northerly colder air masses of maritime and continental origins, whereas the southern part shows the general characteristics of the Mediterranean climate [31]. The average temperature in winter months is between $2{ }^{\circ} \mathrm{C}$ and $9{ }^{\circ} \mathrm{C}$, and in summer months between $18{ }^{\circ} \mathrm{C}$ and $28{ }^{\circ} \mathrm{C}$. The city receives about $815 \mathrm{~mm}$ of precipitation per year as a long-term average, according to the recorded stations in the city [32].

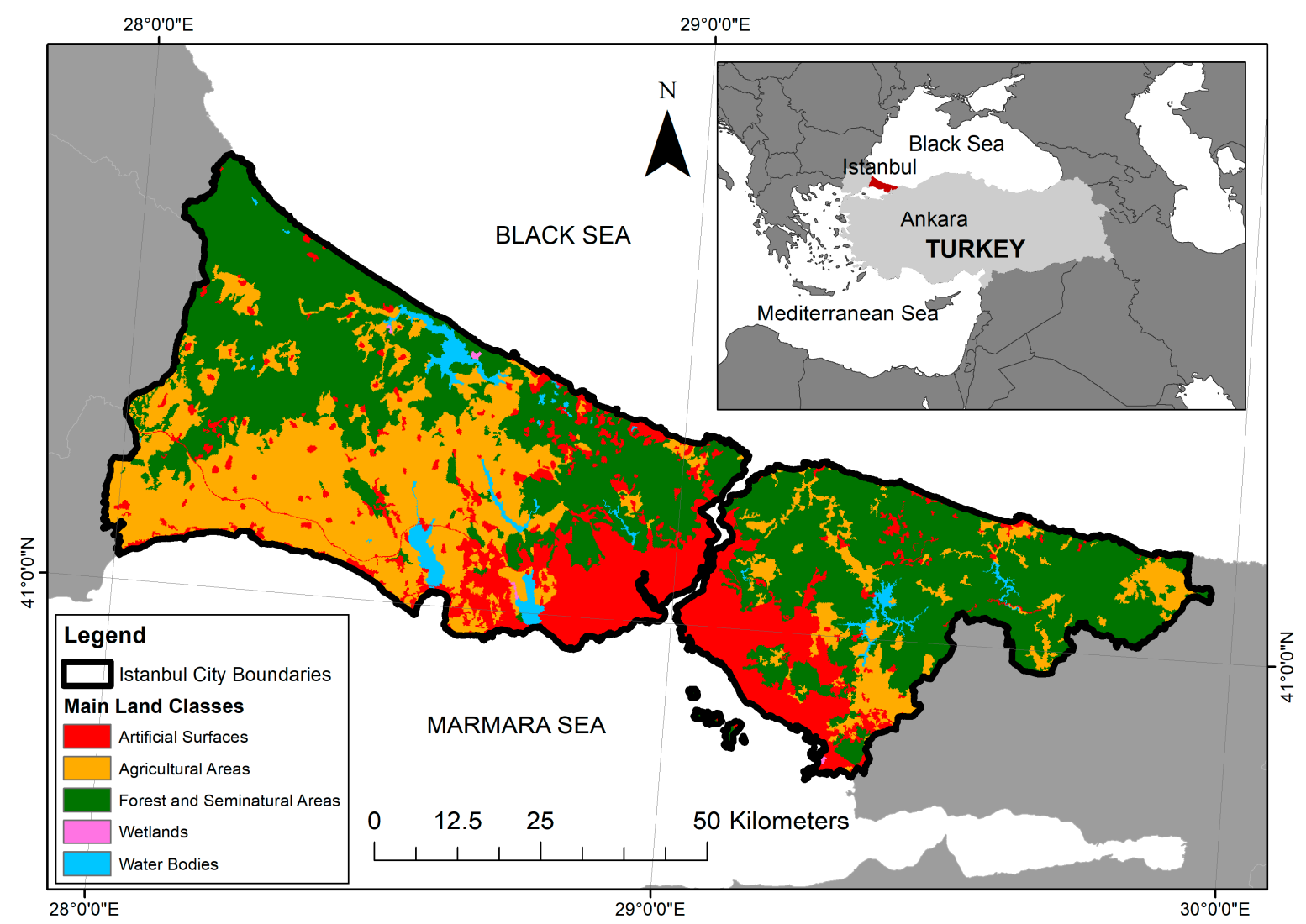

Figure 1. Istanbul city boundary and main land cover classes.

Istanbul has a population of nearly 15 million people, and it is expected that this number will grow to 21 million by 2050 [16,18]. In parallel with the increase in population, daily water consumption will grow due to changes in lifestyle, income level and eating habits. Today, gross water demand in the city is estimated to be $175 \mathrm{~L} /$ capita-day, and this figure is expected to reach $225 \mathrm{~L} /$ capita-day by 2050 including industrial usage and NRW. Figure 2 shows the historical population changes and water demand of Istanbul. 


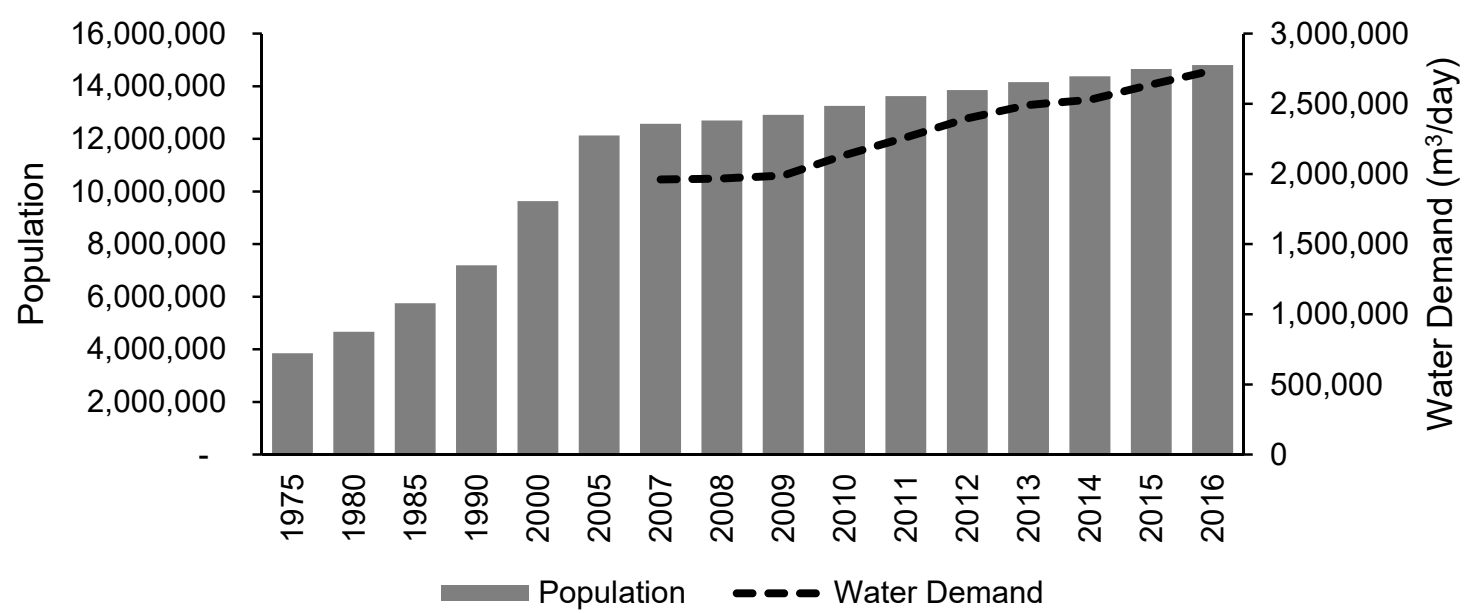

Figure 2. Population changes and annual water demand of Istanbul between 1975 and 2016.

As of today, 15 drinking-water reservoirs operate to meet the demand for potable water in Istanbul. To meet the water demand of the Istanbul metropolitan area, ISKI had to expand its service area beyond the city border (Figure 3). Currently, ISKI is responsible for the management and the protection of the water resources located in different administrative regions to supply drinking water to the Istanbul metropolitan area. There are several ongoing projects to increase the potential water capacity and protect catchments for the future. Six of the main drinking-water reservoirs and their watersheds are within the city border, namely, Terkos, Buyukcekmece, Alibey, Sazlıdere, Omerli, Elmalı and Darlık; and the rest, the Kazandere and Papucdere Reservoirs, Istranca Creeks and the Melen System, are in neighboring cities (Figure 3). Istanbul has an unbalanced distribution in terms of its water resources and population between the Asian and European sides. In numbers, the Asian side has $77 \%$ of the water resources (including the Melen System) while it hosts $35 \%$ of the population (Table 1).

Table 1. Water resources and the population distribution for Istanbul.

\begin{tabular}{ccc}
\hline Water Resources & Population & Annual Water Potential (Million $\mathbf{~ m}^{3} /$ Year) \\
\hline Asian side ${ }^{*}$ & $5,250,000$ & $1909(77 \%)$ \\
European side & $9,750,000$ & $568(23 \%)$ \\
Grand annual total & $15,000,000$ & 2477 \\
\hline Note: * Greater Melen Dam and Melen Stage III Transmission Line included (to be constructed in 2018).
\end{tabular}

There are plans for the Melen watershed, located in the western part of the Black Sea Region and $180 \mathrm{~km}$ to the east of Istanbul (Figure 3), to provide water to Istanbul in the medium and long term [33]. In order to convey water from the Asian side to the European side, a 6-m diameter and 5551-m long Bosphorous tunnel was constructed. The tunnel goes $135 \mathrm{~m}$ below sea level, crossing the two continents, with a capacity to transfer 3 million $\mathrm{m}^{3}$ of water daily [23].

In order to investigate the water-resources availability of Istanbul, we studied the current watersheds of the city as well as the surrounding potential catchments of Istanbul. This area is located between 40.3 to 42.1 north latitude and 27.1 to 31.7 east longitude, which includes the area next to Istanbul, the Black Sea coast of Trakya Region (Istranca Sub-region), Kapıdag Peninsula, Izmit Bay, the Sapanca and Iznik Lake watersheds, downstream of Sakarya River, and the Melen watershed in the Western Black Sea Basin in Turkey (Figure 4). The total study area is around $20,790 \mathrm{~km}^{2}$. Although there are more flow stations maintained by the State Hydraulic Works (DSI) in the region, 25 stations were found to be suitable over the area for this study. Among these, 12 gauge stations are within the current watersheds of Istanbul, and 13 are located in the remaining parts of the study area (Figure 4). 
Thus, we used these hydrometric stations for regionalization of the hydrological model parameters in the ungauged catchments.

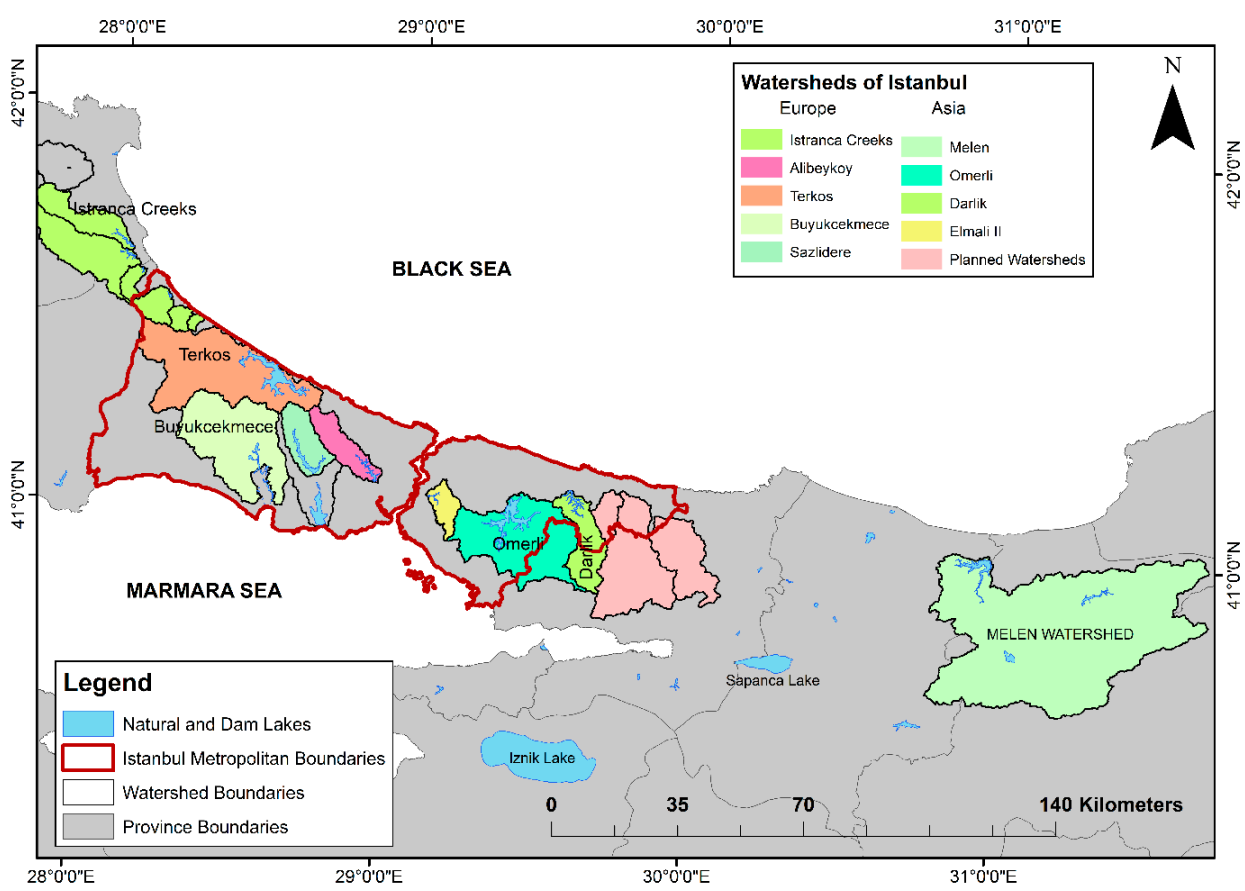

Figure 3. Watersheds used to supply drinking water located both in the Asian and European sides of Istanbul, with administrative boundaries over the region.

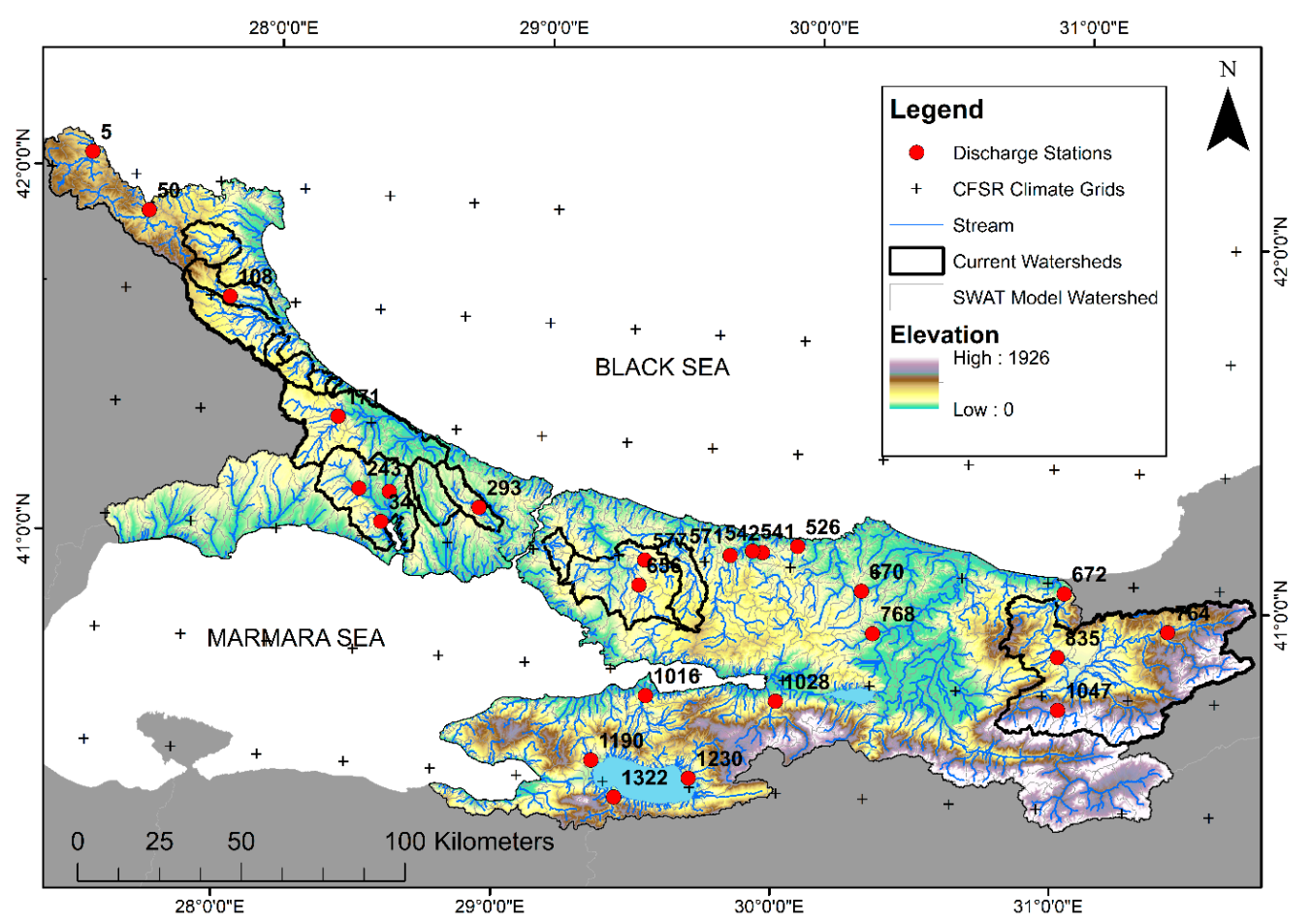

Figure 4. Location of the water resources of Istanbul, topography, rivers, climate grids and discharge stations used in the model. 


\subsection{SWAT Model}

SWAT is a hydrological model developed by the US Department of Agriculture (USDA) Agricultural Research Service [34,35]. It is a continuous-time, semi-distributed, process-based model, developed to evaluate alternative management strategies on water resources and non-point source pollution in large river basins [36].

Water balance is the driving force behind all the processes in SWAT because it impacts plant growth and the movement of sediments, nutrients, pesticides and pathogens [36]. In SWAT, a watershed is divided into multiple sub-basins, which are then further subdivided into hydrologic response units (HRUs) based on unique combinations of land use, soil, management and topographical features. The model simulates hydrology of a watershed in two phases. In the first phase, called the land phase, the hydrological processes of a watershed are simulated at the HRU level and water balance calculated for each sub-basin. The pathways of water movement in the land phase simulated by SWAT are given as canopy storage, surface runoff, evapotranspiration, infiltration, lateral sub-surface flow, return flow, revap from shallow aquifers, and percolation to the deep aquifer. In the second phase (the routing phase), after the loadings of water, sediment, nutrients and pesticides are determined, and loadings are routed through streams and reservoirs within the watershed [37]. A schematic representation of hydrological cycle elements simulated by SWAT is given in Figure 5.

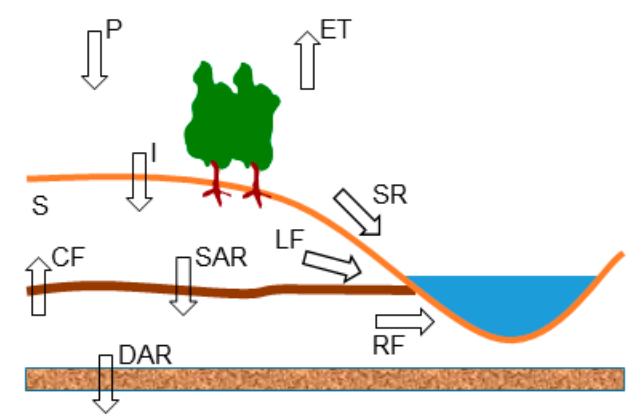

$$
\begin{array}{ll}
\mathrm{P} & =\text { Precipitation } \\
\text { ET } & =\text { Evapotranspration } \\
\text { I } & =\text { Infiltration } \\
\text { SR } & =\text { Surface runoff } \\
\text { RF } & =\text { Return flow } \\
\text { LF } & =\text { Lateral flow } \\
\text { CF } & =\text { Capillary flow } \\
\text { SAR } & =\text { Shallow Aquifer Recharge } \\
\text { DAR } & =\text { DeepAquifer Recharge } \\
\text { S } & =\text { Soil Moisture }
\end{array}
$$

Figure 5. Schematic representation of hydrological cycle elements in SWAT.

More details and model equations can be found in the SWAT technical documentation (http://swatmodel.tamu.edu) and in Arnold et al. [34]. A general overview of SWAT model use, calibration and validation is discussed by Arnold et al. [36], and historical development, applications, and future research directions are summarized in Gasmann et al. [38] and Douglas-Mankin et al. [35].

\subsection{Model Inputs and Setup}

The SWAT model requires a land-use map, climate data, soil map, and topography. Due to the lack of local data to build a model, data required for this study were compiled from global datasets. River discharges and water consumption rates were obtained from local administrations (Table 2).

The soil map was produced by the Food and Agriculture Organization/United Nations Educational, Scientific and Cultural Organization (FAO-UNESCO) global soil map [39], which provides data for 5000 soil types (65 for Turkey) comprising two layers $(0-30 \mathrm{~cm}$ and 30-100 cm depth) at a spatial resolution of $10 \mathrm{~km}$. The land-use map was obtained from the CORINE 2000 Land Cover datasets (http:/ / www.eea.europa.eu/data-and-maps / data/corine-land-cover-2000-raster-3) at a resolution of 100. A digital elevation model (DEM) was constructed from the Shuttle Radar Topography Mission (SRTM) database at a 90-m spatial resolution (http://srtm.csi.cgiar.org/). Three different climate database sources were available for the region: (1) measured data collected from the State Meteorological Service (MGM) in 17 temperature and rainfall climate stations with $<15 \%$ missing data for the period 1960-2013; (2) gridded data constructed from Climate Research Units 
(CRU) with a $0.5^{\circ}$ resolution for the period $1970-2007$, and $0.25^{\circ}$ gridded data from Climate Forecast System Reanalysis (CFSR) for the period 1979-2014, amounting to 48 and 103 grid points, respectively.

Table 2. Data description, source, and resolution in the current study.

\begin{tabular}{lll}
\hline Data Type & Source & $\begin{array}{l}\text { Data } \\
\text { Resolution }\end{array}$ \\
\hline $\begin{array}{l}\text { Digital elevation map } \\
\text { (DEM) }\end{array}$ & Shuttle Radar Topography Mission (SRTM) http://srtm.csi.cgiar.org/ & $90 \mathrm{~m}$ \\
\hline Land use & $\begin{array}{l}\text { European Environment Agency CORINE Land Cover (year 2000) } \\
\text { http://www.eea.europa.eu/data-and-maps/data/corine-land-cover- } \\
\text { 2000-raster-3 }\end{array}$ & $100 \mathrm{~m}$ \\
\hline Soil & $\begin{array}{l}\text { FAO-UNESCO global soil map http: } \\
\text { //www.fao.org/nr/land/soils/digital-soil-map-of-the-world/en/ }\end{array}$ & $5 \mathrm{~km}$ \\
\hline Climate data & $\begin{array}{l}\text { Climate Research Unit http://www.cru.uea.ac.uk } \\
\text { Climate Forecast System Reanalysis (CFSR) } \\
\text { http://cfs.ncep.noaa.gov/cfsr/ } \\
\text { Turkish State of Meteorological Service http://www.mgm.gov.tr/ }\end{array}$ & $0.5^{\circ}$ \\
\hline $\begin{array}{l}\text { River discharge } \\
\text { Population and water } \\
\text { consumption rates }\end{array}$ & $\begin{array}{l}\text { Turkish State of Hydraulics http://en.dsi.gov.tr/ } \\
\text { Istanbul Water and Sewage Administration www.iski.gov.tr/ }\end{array}$ & \begin{tabular}{l} 
Thtions \\
\hline
\end{tabular} \\
\hline
\end{tabular}

We used the ArcSWAT 2012 interface to set up the model. Despite using a high-resolution DEM in the model, in order to avoid the discrepancies, particularly during the stream network delineation, we used the burn-in feature of ArcSWAT with river data obtained from the Google Earth software. Also, to delineate coastal catchment areas more accurately, a threshold drainage area of $100 \mathrm{ha}$ was chosen. Inland sub-basin outlets were manually added to represent reservoirs, gauge stations, main river channels, and other topographical features in the watershed; while coastal outlets were created automatically by the software based on the given threshold. As a result, the study area was configured with 1335 sub-basins, which were further discretized into 3315 HRUs. The model could not represent $4 \%$ of the real area as a result of the precision of basin delineation near the coastal zones. However, this missing area does not affect principal objectives of the study. The total simulated area in the current model is $19,960 \mathrm{~km}^{2}$.

Except for two stream gauges, none of the gauges are affected by the reservoir operations. Therefore, we did not use the reservoir operation rule in the current model. The available river discharge data in the region varies between 10 years and 32 years. Five elevation bands in each sub-basin were established to adjust for orographic change in temperature $\left(-6.5^{\circ} \mathrm{C} \mathrm{km}^{-1}\right)$ and rainfall $\left(100 \mathrm{~mm} \mathrm{~km}^{-1}\right)$. Potential evapotranspiration (PET) is simulated using Hargreaves method [40], actual evapotranspiration (ET) is estimated based on the methodology of Ritchie [41], and surface runoff is calculated by the Soil Conservation Service (SCS) curve number procedure [42].

According to the acquired data (Table 2), the model was simulated from 1977 to 2013 (37 years), and the first 3 years were used as a warm-up period to allow the processes simulated to reach a dynamic equilibrium and decrease the uncertainty of the initial conditions of the model. The simulation includes both dry and wet years occurring in the historical period. Figure 6 depicts the yearly cumulative precipitation in Istanbul between the years 1977 and 2014, including both drought and wet periods. 


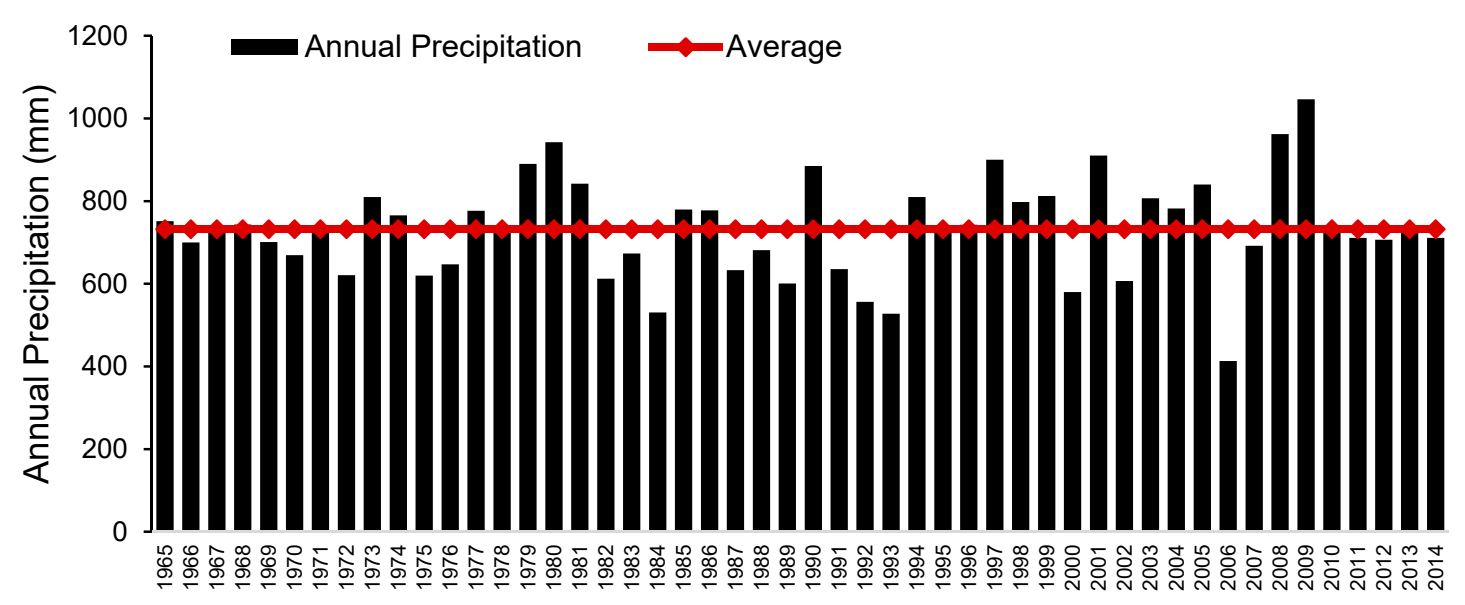

Figure 6. Annual precipitation of Istanbul including severe dry and wet periods for the city in the last 50 years.

Due to the availability of more than one climate database, we evaluated three different datasets as a preliminary analysis of the model. According to the preliminary model results during the model set-up, CFSR outperformed the local dataset and CRU captured better the streamflow dynamics and also the total rainfall distribution over the study area. Most of the watershed area evaluated in this study are protected zones without any settlements [24], thus land-use changes are negligible.

For model calibration, validation and uncertainty analysis we used the SUFI-2 algorithm $[43,44]$ in the SWAT-CUP software. All uncertainties in the model, such as a parameter, measured data (e.g., stream flow), driving variables (e.g., rainfall), and conceptual framework, are expressed as a set of parameter ranges by SUFI-2. The algorithm tries to capture most of the measured data within the $95 \%$ band of prediction uncertainty (95PPU). The uncertainty (95PPU) is quantified at the $2.5 \%$ and $97.5 \%$ levels of the cumulative frequency distribution of an output variable obtained using the Latin hypercube sampling technique. Two indices are used to measure the goodness of calibration/uncertainty performance, the P-factor (ranges 0 to 1), which is the percentage of data captured by 95PPU band, and the R-factor (ranges 0 to $\infty$ ), which is the average thickness of the uncertainty band divided by the standard deviation of the related measured variable $[43,44]$. These two indices are used to judge the strength of the calibration procedure where a value of $>0.7$ for the P-factor and a value of around 1 for the R-factor would be satisfactory, depending on the study [11,12]. More information about the algorithm is given by Abbaspour et al. [11,44]. SUFI-2 allows the use of different objective functions such as $\mathrm{R}^{2}$, RSR or Nash-Sutcliffe efficiency (NSE) [45]. Despite the fact that we used NSE as an objective function, percent bias (PBIAS) [46] and $\mathrm{R}^{2}$ of the calibration/validation results were also evaluated as well as the P-factor and the R-factor in order to assess the model performance and model output uncertainty.

\section{Results and Discussion}

\subsection{Calibration and Validation of River Discharges}

Although SWAT parameterization has been done based on the parameters given in Table 3 together with initial and final ranges for the calibration, in order to improve model performance especially in high altitudes where snow processes become predominant, we changed the snow melt temperature (SMTMP), snow fall temperature (SFTMP), and maximum and minimum snowmelt rate factors (SMFMX, SMFMN) to $-3.71,3.21,5.68$ and 3.05, respectively. These numbers were obtained after several simulations in SWAT-CUP. Adjusting the parameter related to snow processes improves the model's performance, in particular at the discharge stations located in mountainous region of the study area. After fixing these parameters (to their best values obtained by the preliminary runs), 
the protocol given in Abbaspour et al. [11] was followed for calibration/validation as well as sensitivity and uncertainty analysis.

Table 3. List of the model calibration parameter.

\begin{tabular}{|c|c|c|c|c|c|}
\hline SWAT Parameter & Definition & $\begin{array}{l}\text { Initial } \\
\text { Range }\end{array}$ & Final Range & $t$ Value & $p$ Value \\
\hline $\mathrm{r} \_\mathrm{CN} 2 . \mathrm{mgt}$ & $\begin{array}{l}\text { SCS runoff curve number for } \\
\text { moisture condition II }\end{array}$ & -0.5 to 0.5 & -0.20 to 0.39 & -9.742 & $6.73 \times 10^{-21}$ \\
\hline r_SOL_AWC().sol & $\begin{array}{l}\text { Soil available water storage capacity } \\
\qquad\left(\mathrm{mm} \mathrm{H}_{2} \mathrm{O} / \mathrm{mm} \text { soil }\right)\end{array}$ & -0.5 to 0.5 & -0.06 to 0.80 & 0.390 & 0.696 \\
\hline r_GW_REVAP.gw & Groundwater revap. coefficient & -0.5 to 0.5 & -0.13 to 0.60 & 0.033 & 0.973 \\
\hline r_GWQMN.gw & $\begin{array}{l}\text { Threshold depth of water in shallow } \\
\text { aquifer for return flow (mm) }\end{array}$ & -0.5 to 0.5 & -0.52 to 0.15 & -1.615 & 0.106 \\
\hline r_REVAPMN.gw & $\begin{array}{l}\text { Threshold depth of water in the } \\
\text { shallow aquifer for "revap" (mm) }\end{array}$ & -0.5 to 0.5 & -0.50 to 0.16 & 1.695 & 0.090 \\
\hline
\end{tabular}

Note: The term " $\mathrm{r}$ _" was used for the relative changes in the parameter between the ratio of a given range, "()" was used for all layers of soil, and the extension of the parameter states the file name of the SWAT files.

Nine SWAT parameters were selected for model calibration for all discharge stations. Half of the river discharge data were used for calibration and the remainder were used for validation. The parallel processing option of SWAT-CUP [47] considerably reduced the model simulation time. One iteration and 600 simulations with nine parameters were adequate for obtaining satisfactory calibration and validation results. There are different gridded climate datasets covering the region of our study. Using these datasets could be quite useful for evaluating the uncertainty caused by using different input data [48]. Furthermore, scientists may consider the possibility of using a stochastic hydrological rainfall-runoff model if there are not enough data of precipitations in a specific study area $[49,50]$.

As expected, the CN2 parameter was the most sensitive parameter for outflow, followed by ALPHA_BF. Although the SOL_BD and GW_REVAP parameters seemed to be less sensitive as indicated by their $t$-stat and $p$-value (Table 3), they contributed to increased model calibration results for river discharges considerably. $t$-stat depicts parameter sensitivity: the larger the $t$-value, the more sensitive the parameter; whereas the $p$-value indicates the significance of the $t$-value: the smaller the $p$-value, the less chance of a parameter being accidentally assigned as sensitive [11].

Twenty-five gauge stations on discontinuous stream networks were parameterized and calibrated simultaneously. $\mathrm{R}^{2}$ ranges from 0.39 to 0.82 for calibration, and 0.41 to 0.82 for validation, while NSE values vary from 0.31 to 0.81 for calibration, and 0.33 to 0.81 for validation. Model outputs for most of the discharge stations can be judged as satisfactory according to Moriasi et al. [51]. Table 4 represents the calibration and validation results and model performance criteria for the 25 gauges stations used in this study.

Except for the two gauge stations (Nos.: 1190 and 1322) our simulations captured the $60-90 \%$ (P-factor values ranges from 0.6 to 0.9 ) of observed data during simulation (Table 4). Poor simulation results at these stations originate from high base-flow simulations in dry periods and high peak simulations during wet periods. This is due to the CFSR climate station located in the east of the Iznik Lake (Figure 4), which overestimates the precipitation in these catchments. The larger R-factor values representing higher uncertainty for the stations (gauge station Nos.: 243, 341 and 656) located on the Istanbul city border, is most likely a result of rapid urbanization having occurred in that catchment in the last few decades. Most of the stations in the study area had $\mathrm{R}^{2}$ and NSE of more than 0.5 both in calibration and validation (Figure 7). Poor simulation results were obtained downstream of areas 
with intensive water-resource development (regulators, water store operations) and urbanization (increasing settlement and urban drainage systems) because of processes that were not included the model.

Table 4. Model performance indicators of 25 gauge stations for calibration and validation.

\begin{tabular}{|c|c|c|c|c|c|c|c|c|c|c|}
\hline \multirow{2}{*}{$\begin{array}{c}\text { Gauge } \\
\text { Station No. }\end{array}$} & \multicolumn{7}{|c|}{ Calibration } & \multicolumn{3}{|c|}{ Validation } \\
\hline & P Factor & R Factor & $\mathrm{R}^{2}$ & NSE & PBIAS & P Factor & R Factor & $\mathbf{R}^{2}$ & NSE & PBIAS \\
\hline 5 & 0.71 & 1.24 & 0.39 & 0.31 & -26.8 & 0.67 & 0.80 & 0.53 & 0.50 & 8.3 \\
\hline 50 & 0.75 & 1.04 & 0.66 & 0.65 & 1.4 & 0.75 & 1.14 & 0.41 & 0.35 & 6.2 \\
\hline 108 & 0.90 & 1.32 & 0.78 & 0.73 & 14.2 & 0.72 & 1.20 & 0.50 & 0.33 & 21.9 \\
\hline 171 & 0.83 & 1.03 & 0.86 & 0.84 & -1.2 & 0.78 & 1.37 & 0.58 & 0.43 & -5.5 \\
\hline 243 & 0.82 & 1.53 & 0.61 & 0.48 & -23.1 & 0.81 & 1.10 & 0.78 & 0.78 & 1.8 \\
\hline 252 & 0.62 & 0.83 & 0.82 & 0.81 & 3.8 & 0.49 & 0.86 & 0.68 & 0.67 & 4.4 \\
\hline 293 & 0.62 & 0.72 & 0.80 & 0.79 & 15.8 & 0.51 & 1.06 & 0.57 & 0.46 & -25.0 \\
\hline 341 & 0.74 & 1.49 & 0.78 & 0.69 & -5.2 & 0.81 & 1.21 & 0.69 & 0.68 & 9.3 \\
\hline 526 & 0.69 & 1.10 & 0.67 & 0.64 & -6.8 & 0.60 & 1.08 & 0.65 & 0.64 & -5.5 \\
\hline 541 & 0.80 & 1.00 & 0.52 & 0.50 & 16.6 & 0.81 & 0.93 & 0.80 & 0.79 & 9.2 \\
\hline 542 & 0.77 & 1.03 & 0.55 & 0.53 & 14.2 & 0.83 & 0.98 & 0.77 & 0.77 & 5.1 \\
\hline 571 & 0.69 & 0.97 & 0.68 & 0.68 & -0.1 & 0.70 & 0.89 & 0.72 & 0.72 & -7.2 \\
\hline 577 & 0.72 & 0.97 & 0.79 & 0.77 & -8.3 & 0.54 & 0.77 & 0.48 & 0.48 & 8.9 \\
\hline 656 & 0.64 & 1.46 & 0.78 & 0.37 & -56.6 & 0.57 & 1.32 & 0.81 & 0.55 & -64.5 \\
\hline 670 & 0.83 & 1.28 & 0.79 & 0.68 & -12.3 & 0.67 & 1.63 & 0.80 & 0.41 & -49.9 \\
\hline 672 & 0.84 & 1.10 & 0.81 & 0.77 & 15.6 & 0.89 & 1.10 & 0.85 & 0.81 & 15.6 \\
\hline 764 & 0.74 & 1.01 & 0.55 & 0.53 & 8.1 & 0.73 & 1.00 & 0.69 & 0.67 & 7.1 \\
\hline 768 & 0.82 & 1.05 & 0.74 & 0.74 & 2.5 & 0.70 & 1.57 & 0.64 & 0.31 & -39.1 \\
\hline 835 & 0.77 & 1.23 & 0.68 & 0.61 & -4.2 & 0.84 & 1.15 & 0.82 & 0.81 & 4.4 \\
\hline 1016 & 0.72 & 1.37 & 0.69 & 0.50 & -33.9 & 0.65 & 1.17 & 0.79 & 0.78 & -13.1 \\
\hline 1028 & 0.73 & 0.70 & 0.64 & 0.59 & 18.3 & 0.74 & 0.89 & 0.69 & 0.61 & 25.3 \\
\hline 1047 & 0.65 & 0.75 & 0.66 & 0.53 & 32.1 & 0.69 & 0.78 & 0.74 & 0.65 & 28.9 \\
\hline 1190 & 0.43 & 0.71 & 0.68 & 0.60 & 3.5 & 0.31 & 1.21 & 0.71 & 0.65 & -31.3 \\
\hline 1230 & 0.78 & 1.20 & 0.74 & 0.72 & -10.3 & 0.76 & 1.18 & 0.74 & 0.74 & -2.0 \\
\hline 1322 & 0.32 & 0.68 & 0.62 & 0.59 & -14.0 & 0.25 & 0.57 & 0.57 & 0.52 & -6.2 \\
\hline
\end{tabular}
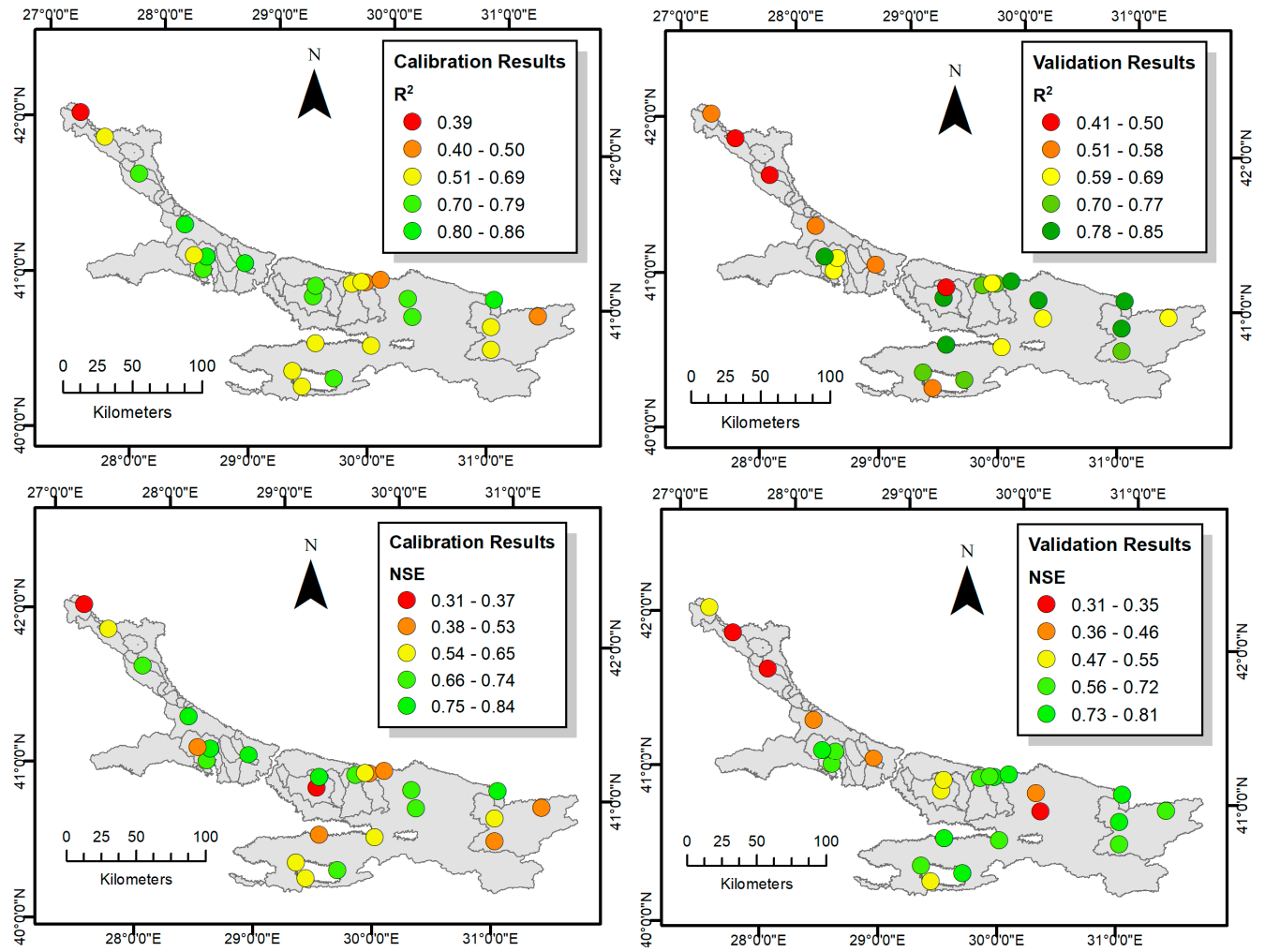

Figure 7. Comparison of simulated and observed discharge data using the coefficient of determination $\left(\mathrm{R}^{2}\right)$ and Nash-Sucthlife coefficient (NSE) for the calibration and validation period. 
Average discharge rates of the rivers in the study area varies from $0.2 \mathrm{~m}^{3} \mathrm{~s}^{-1}$ to $44 \mathrm{~m}^{3} \mathrm{~s}^{-1}$ (Figure 8). Extreme discharge values of about $150 \mathrm{~m}^{3} \mathrm{~s}^{-1}$ were captured by our model quite well. For the simplicity and clarity of graphs, calibration and validation periods are shown in one graph continuously (Figure 8).
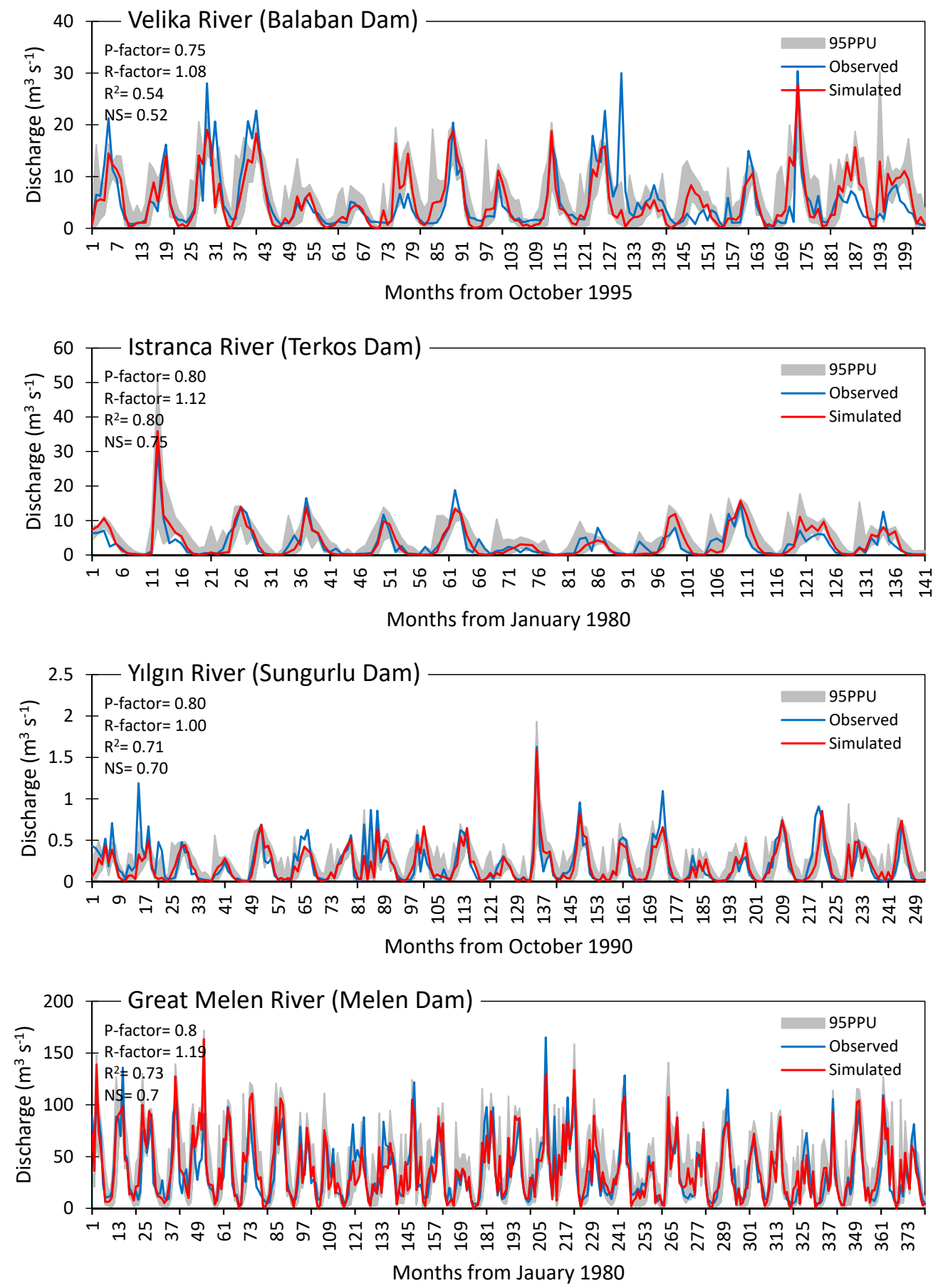

Figure 8. Illustration of the SWAT-CUP output for the simulation period depicting the observed, simulated and 95\% prediction uncertainty (95PPU). These hydrographs belong to gauge station Nos. 50, 243,542 and 835 , respectively. 


\subsection{Water Availability}

To show the spatial distribution of precipitation, mean annual rainfall is depicted over the study area (Figure 9a). The catchments on the Black Sea coast of the Asian side receive the highest average annual rainfall in the study area where the major water resources of the city are located. The southern part of Istanbul, with an average annual rainfall of 550-720 mm, receives the least amount of precipitation. Model results of blue and green water are represented at the $50 \%$ probability level of the the 95PPU for the period 1977-2013. These were calculated for 1335 sub-basins (Figure 9b-d). Blue-water (water yield + deep percolation) potential of the watershed on the Asian side is greater than the European side; likewise, green-water storage (soil moisture) (Figure 9b,c). The results reveal that the average blue-water potential of Istanbul is $630 \mathrm{~mm}$, whereas the green-water flow and storage are $382 \mathrm{~mm}$ and $129 \mathrm{~mm}$, respectively.
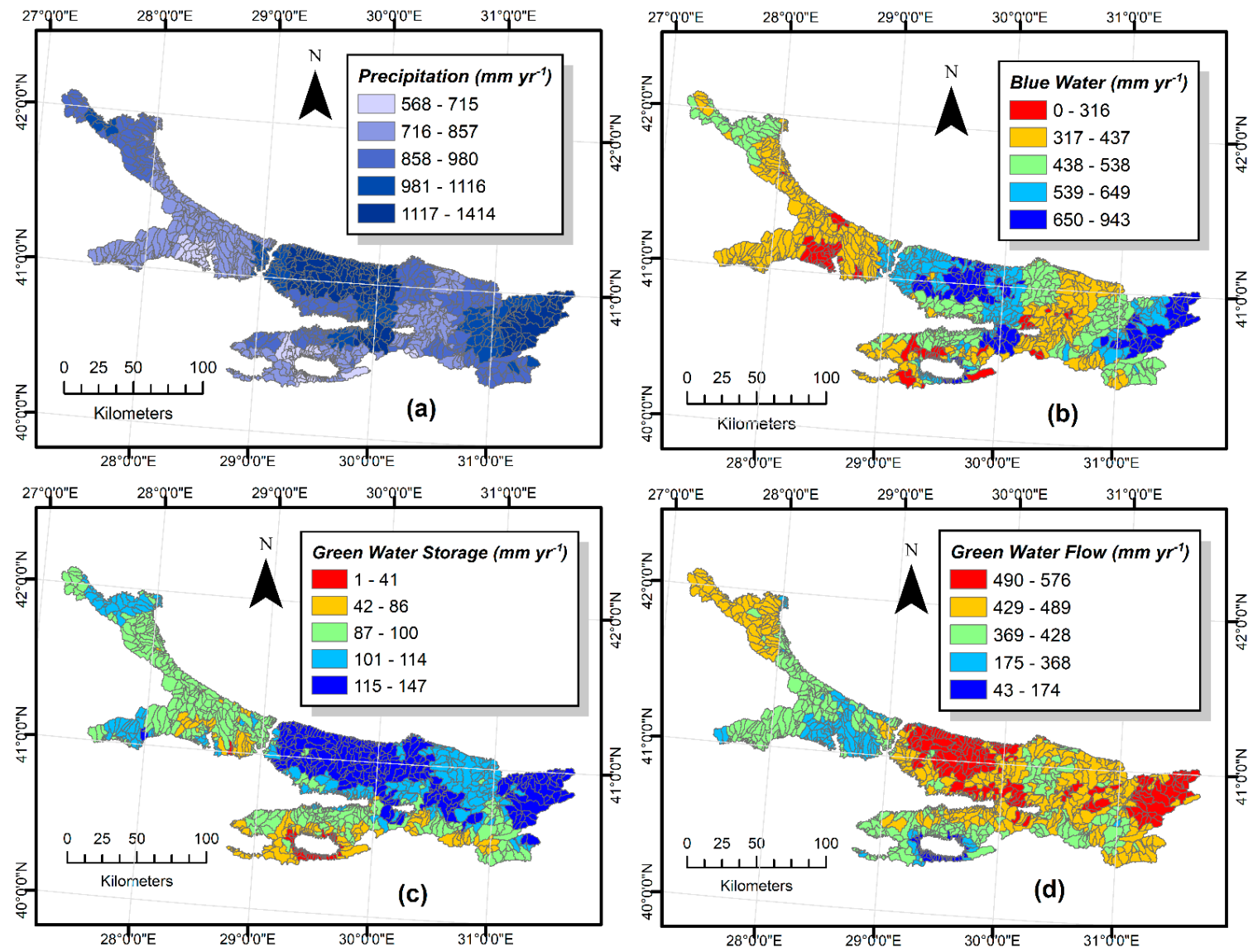

Figure 9. Spatial distribution of simulated average (1980-2013) annual (a) precipitation; (b) blue-water resources; (c) green-water flow and (d) green-water storage for the study area.

Blue-water potentials reach up to $943 \mathrm{~mm} \mathrm{year}^{-1}$ in some catchments such as Omerli, Darlık and Melen which are located on the Black Sea coast. Besides, Buyukcekmece represents poor potential ranging from 0 to $316 \mathrm{~mm}_{\text {year }}{ }^{-1}$ due to less precipitation and a higher potential evapotranspiration rate as well as urbanization in that catchment. The spatial distribution of soil moisture (green-water storage) indicates higher values ranging from 100 to $150 \mathrm{~mm}_{\text {year }}{ }^{-1}$, especially in the eastern part of the study area (Figure 9c). In the current situation, small-scale rainfed agricultural activities play an important role for local villages. Therefore, optimal management strategies are necessary to achieve a balance between supplying water to Istanbul and supporting the agricultural activities and economic growth as well as sustaining high water quality in this region. As shown in Figure 9d, due to the amount 
of available water for transpiration and evaporation, green-water flows in Asian-side watersheds (495 $\mathrm{mm}_{\text {year }}{ }^{-1}$ ) are higher in comparison to the European side (386 $\mathrm{mm} \mathrm{year}^{-1}$ ).

To illustrate the reliability of water resources over the years, we calculated the coefficient of variation $C V=\sigma / \mu \times 100$ for the years 1980-2013 in each sub-basin (Figure 10), where $\sigma$ is the standard deviation and $\mu$ is the mean of the variable.
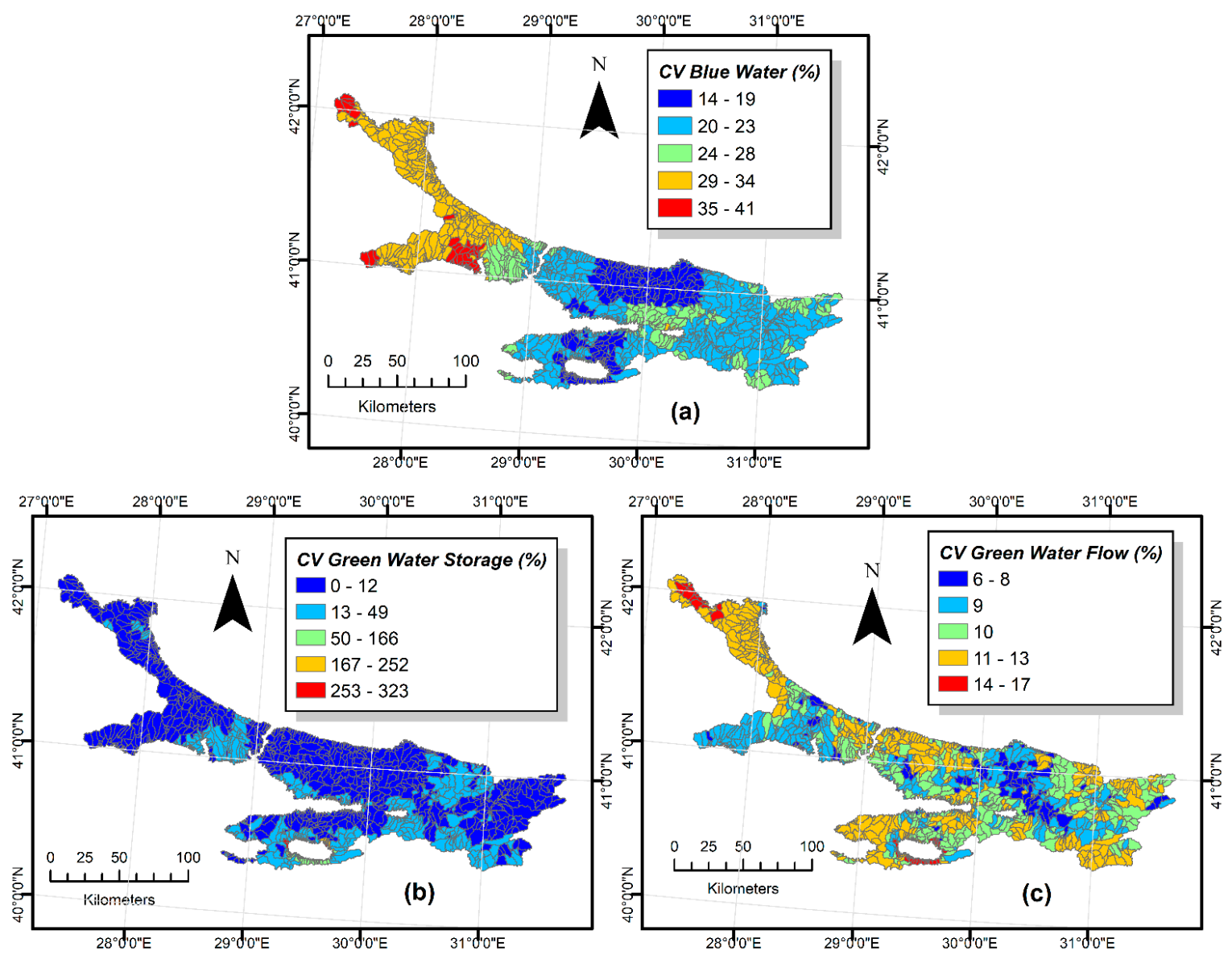

Figure 10. Coefficient of variation (CV) of the modelled annual (1980-2013) (a) blue-water resources; (b) green-water flow and (c) green-water storage.

$\mathrm{CV}$ is an indicator of the reliability of the water resources from year to year [9]. The smaller the $\mathrm{CV}$, the smaller the year-to-year variability of a variable and the more reliable the estimates. Blue-water flows are quite important due to their contribution to the reservoir used for domestic water demand. Although the temporal variation of the blue-water resources is not very large, water resources on the Asian side seem more reliable than the European side, especially in the Darlik, Sungurlu, Isaköy and Kabakoz watersheds, which have the smallest CV values in the study area (Figure 10a). These values indicate a higher reliability of this resource over time and, hence, a less risky opportunity for a water-supplying project. Green-water storage (soil moisture) is generally relatively less variable in most of the area between the values $0-49 \%$, except the catchments near Iznik Lake, which is located in southern part of the study area, and which has CV values between 167\% and 303\% (Figure 10b). This situation is most likely caused by excessive industrial consumption and agricultural irrigation in the region. Temporal variation of evapotranspiration (green-water flow) varies over the study area (Figure 10c) and larger values are obtained in the eastern part of the study area where water availability is greater (Figure 9d).

Model results in hru level aggregated to watershed level and the water potential of each reservoir include both Asian and European sources as well as the current and planned water resources together. 
We calculated the water potential by multiplying the catchment area with blue-water potential (water yield + deep aquifer recharge) of each watershed, and plotted $95 \%$ prediction uncertainty band for each (Figure 11).

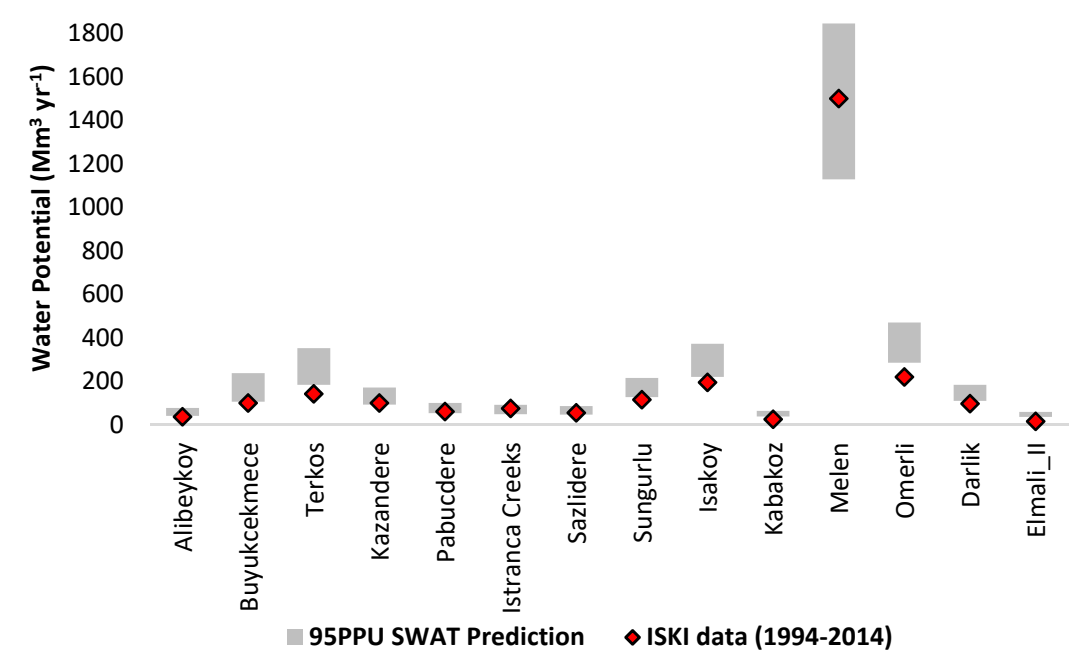

Figure 11. Comparison of the simulated 95PPU SWAT prediction (1980-2013) for water potential with the available data from the Istanbul Water and Sewerage Administration (ISKI) for the watersheds of Istanbul.

As shown in Figure 11 the ISKI estimates are within or close to the 95PPU of our model predictions. Larger differences between model results and ISKI values are observed in the watersheds that are the major reservoirs of Istanbul. This result might be due to possible water losses such as evaporation from the reservoirs, transfer operations, water usage in the watershed, and the effects of urban drainage systems, which were not included in our calculations of water potential for ISKI. Thus, our model gives the "gross" water potential of each watershed. A considerable part of water losses occurs in aged and poorly managed water distribution systems [52-54]. This phenomenon needs to be measured and calculated in detail to estimate the "net" water potential of the city.

According to the prediction of water potential, the watersheds located on the Asian side constitute almost $75 \%$ of the total water resources of Istanbul. The Melen watershed has the highest water potential with 1.5 billion $\mathrm{m}^{3}$ year ${ }^{-1}$ ( $45 \%$ of total water resources), and is followed by Omerli, Terkos, and Buyukcekmece, which are currently in use. These three watersheds will be essential for the city considering their large water potential. The Omerli, Terkos and Buyukcekmece sources will meet 25\% of the total demand in future. As these sources are located in the Istanbul administrative boundary and under pressure of urbanization, protection of these catchments will assure adequate water supply to the city next to the planned resources (Kabakoz, Isakoy and Sungurlu catchments).

Figure 11 also shows that the parameter range obtained using data from 25 discharge stations simultaneously yields quite satisfactory results for the ungauged basin in regions such as Elmali II, Darlik, Istanca Creeks, Kazandere and Papucdere.

\section{Conclusions}

Socio-economic developments, rapid urbanization, and population increase have put pressures on Istanbul's water resources in the last few decades. Thus, matching the water demand of the city requires effective water-management strategies and more projects to supply water from different administrative boundaries. Quantification of available water is an essential part of the management of the water resource of Istanbul. This study contributes significant insights into the water availability of the city and its vicinity, at both regional and watershed level. 
Model results reveal that watersheds supplying drinking water on the Asian side are more reliable and more abundant. However, the majority of the population (thereby most of the water demand) is on the European side; planned water resources for the future are mostly located on the Asian side and are outside the city boundaries. Water transfers from these catchments are vital to meeting the water demands of Istanbul.

Water resources on the Asian side encompass almost $75 \%$ of the total potential. These catchments (except Omerli) are pristine and so far not affected by heavy urbanization. Therefore, optimal management strategies in these catchments play a significant role in balancing water supply and local activities (agriculture, energy production, recreation etc.). Also, protection of these catchments in terms of not only water quantity but also quality is vital to the city. The Melen watershed is of utmost importance as it will provide $45 \%$ of the total water demand of the city in the future. Melen and its significant water potential (1.5 billion $\mathrm{m}^{3}$ per year) could be highly beneficial in the case of increasing population and in drought periods. In addition to increased water potential capacity, water re-use, decreasing water loss in the supply network, upgrading urban drainage system, rainwater harvesting, and the efficient use of available water will make better use of available water in Istanbul.

More detailed analysis in the study area covering quantitative assessment of each watershed for different scenarios such as drought, socio-economic change, land-use conditions, as well as climate change scenarios, could provide more information and significant knowledge of value to policy-makers, local administrators and experts. The well-established and calibrated model developed in this study provides a strong basis for forthcoming studies in the Istanbul megacity regarding reservoir operations and management, the impact of climate change, as well as water-quality and biodiversity issues in the reservoirs.

Acknowledgments: This project was funded by the Scientific and Technological Research Council of Turkey (TUBITAK) 2214 Grand Program, and Istanbul Technical University, Scientific Research Projects Fund (Project \# 40227). The first author would like to thank Aysegul Tanik for her valuable comments on this manuscript.

Author Contributions: Gokhan Cuceloglu performed the data compilation, simulations, analysis, and drafted the manuscript. Karim C. Abbaspour and Izzet Ozturk made contributions in reviewing and editing the manuscript.

Conflicts of Interest: The authors declare that they have no conflicts of interest.

\section{References}

1. IPCC. Climate Change 2013: The Physical Science Basis. Contribution of Working Group I to the Fifth Assessment Report of the Intergovernmental Panel on Climate Change; Stocker, T.F., Qin, D., Plattner, G.-K., Tignor, M., Allen, S.K., Boschung, J., Nauels, A., Xia, Y., Bex, V., Midgley, P.M., Eds.; Cambridge University Press: Cambridge, UK; New York, NY, USA, 2013.

2. Christensen, J.H.; Kumar, K.K.; Aldria, E.; An, S.-I.; Cavalcanti, I.F.A.; De Castro, M.; Dong, W.; Goswami, P.; Hall, A.; Kanyanga, J.K.; et al. Climate Phenomena and their Relevance for Future Regional Climate Change Supplementary Material. In Climate Change 2013: The physical Science Basis. Contribution of Working Group I to the Fifth Assessment of the Intergovernmental Panel on Climate Change; Cambridge University Press: Cambridge, UK, 2013; pp. 1217-1308. [CrossRef]

3. Erol, A.; Randhir, T.O. Climatic change impacts on the ecohydrology of Mediterranean watersheds. Clim. Chang. 2012, 114, 319-341. [CrossRef]

4. World Water Assessment Programme. The United Nations World Water Development Report 3: Water in a Changing World; UNESCO: Paris, France; Earthscan: London, UK, 2009.

5. Mariotti, A.; Zeng, N.; Yoon, J.-H.; Artale, V.; Navarra, A.; Alpert, P.; Li, L.Z.X. Mediterranean water cycle changes: Transition to drier 21st century conditions in observations and CMIP3 simulations. Environ. Res. Lett. 2008, 3, 44001. [CrossRef]

6. Biswas, A.K. Water Management for Major Urban Centres. Int. J. Water Resour. Dev. 2006, 22, $183-197$. [CrossRef]

7. Varis, O.; Biswas, A.K.; Tortajada, C.; Lundqvist, J. Megacities and Water Management. Int. J. Water Resour. Dev. 2006, 22, 377-394. [CrossRef] 
8. Falkenmark, M.; Rockström, J. The New Blue and Green Water Paradigm: Breaking New Ground for Water Resources Planning and Management. J. Water Resour. Plan. Manag. 2006, 132, 129-132. [CrossRef]

9. Schuol, J.; Abbaspour, K.C.; Yang, H.; Srinivasan, R.; Zehnder, A.J.B. Modeling blue and green water availability in Africa. Water Resour. Res. 2008, 44. [CrossRef]

10. Veettil, A.V.; Mishra, A.K. Water security assessment using blue and green water footprint concepts. J. Hydrol. 2016, 542, 589-602. [CrossRef]

11. Abbaspour, K.C.; Rouholahnejad, E.; Vaghefi, S.; Srinivasan, R.; Yang, H.; Kløve, B. A continental-scale hydrology and water quality model for Europe: Calibration and uncertainty of a high-resolution large-scale SWAT model. J. Hydrol. 2015, 524, 733-752. [CrossRef]

12. Rouholahnejad, E.; Abbaspour, K.C.; Srinivasan, R.; Bacu, V.; Lehmann, A. Water resources of the Black Sea Basin at high spatial and temporal resolution. Water Resour. Res. 2014, 50, 5866-5885. [CrossRef]

13. Rodrigues, D.B.B.; Gupta, H.V.; Mendiondo, E.M. A blue/green water-based accounting framework for assessment of water security. Water Resour. Res. 2014, 50, 7187-7205. [CrossRef]

14. Zang, C.F.; Liu, J.; Van Der Velde, M.; Kraxner, F. Assessment of spatial and temporal patterns of green and blue water flows under natural conditions in inland river basins in Northwest China. Hydrol. Earth Syst. Sci. 2012, 16, 2859-2870. [CrossRef]

15. Faramarzi, M.; Abbaspour, K.C.; Schulin, R.; Yang, H. Modelling blue and green water resources availability in Iran. Hydrol. Process. 2009, 23, 486-501. [CrossRef]

16. TUIK Address-Based Population Registration Database System Turkish Statistical Institute Official Website. Available online: http:/ / www.tuik.gov.tr/UstMenu.do?metod=temelist (accessed on 14 January 2016).

17. Van Leeuwen, K.; Sjerps, R. Istanbul: The challenges of integrated water resources management in Europa's megacity. Environ. Dev. Sustain. 2016, 18, 1-17. [CrossRef]

18. Istanbul Master Plan Consortium (IMC). Istanbul Water Supply, Sewage and Drainage, Wastewater Treatment, and Disposal Master Plan; Istanbul Master Plan Consortium: Istanbul, Turkey, 1999.

19. Akkoyunlu, A.; Yuksel, E.; Erturk, F.; Bayhan, H. Managing of watersheds of Istanbul (Turkey). In Proceedings of the Fifth Water Information Summit: Regional Perspectives on Water Information Management Systems, Ft. Lauderdale, FL, USA, 23-25 October 2002.

20. Eroglu, V.; Sarikaya, H.Z.; Ozturk, I.; Yuksel, E.; Soyer, E. Water management in Istanbul Metropolitan Area. In Proceedings of the Third International Forum, Integrated Water Management: The key to sustainable water resources, Athens, Greek, 21-22 March 2002.

21. Yuksel, E.; Eroglu, V.; Sarikaya, H.Z.; Koyuncu, I. Current and Future Strategies for Water and Wastewater Management of Istanbul City. Environ. Manag. 2004, 33, 186-195. [CrossRef] [PubMed]

22. Altinbilek, D. Water Management in Istanbul. Int. J. Water Resour. Dev. 2006, 22, 241-253. [CrossRef]

23. Saatci, A.M. Solving Water Problems of a Metropolis. J. Water Resour. Prot. 2013, 5, 7-10. [CrossRef]

24. Ozturk, I.; Altay, D.A. Water and Wastewater Management in Istanbul. In Proceedings of the UNESCO HQ International Conference on Water, Megacities and Global Change, Paris, France, 1-4 December 2015.

25. Cuceloglu, G.; Erturk, A. Model Supported Hydrological Analysis of Darlik Creek Watershed, Istanbul Turkey. Fresenius Environ. Bull. 2014, 23, 3110-3116.

26. Akiner, M.E.; Akkoyunlu, A. Modeling and forecasting river flow rate from the Melen Watershed, Turkey. J. Hydrol. 2012, 456-457, 121-129. [CrossRef]

27. Kara, F.; Yucel, I. Climate change effects on extreme flows of water supply area in Istanbul: Utility of regional climate models and downscaling method. Environ. Monit. Assess. 2015, 187. [CrossRef] [PubMed]

28. Istanbul Water and Sewerage Administrationon (ISKI). Climate Change Impacts on Istanbul and Turkey Water Resources Project Final Report; Istanbul Water and Sewerage Administrationon (ISKI): Istanbul, Turkey, 2010.

29. Cuceloglu, G.; Ozturk, I. Development of a Model Framework for Sustainable Water Management Practices: Case Study for the Megacity Istanbul. In Proceedings of the 9th Eastern European Young Water Professionals Conference, The International Water Association, Budapest, Hungary, 24-24 May 2017.

30. Cuceloglu, G.; Ozturk, I. Assessing the Influence of Climate Datasets for Quantification of Water Balance Components in Black Sea Catchment: Case Study for Melen Watershed in Turkey. In Proceedings of the International SWAT Conference, Warsaw, Poland, 26-30 July 2017.

31. Ezber, Y.; Sen, O.L.; Kindap, T.; Karaca, M. Climatic effects of urbanization in Istanbul: A statistical and modeling analysis. Int. J. Climatol. 2007, 27, 667-679. [CrossRef] 
32. MGM Turkish State of Meteorological Service. Available online: https://www.mgm.gov.tr/ veridegerlendirme/il-ve-ilceler-istatistik.aspx?k=undefined\&m=ISTANBUL (accessed on 12 January 2017).

33. Ozturk, I.; Erturk, A.; Ekdal, A.; Gurel, M.; Cokgor, E.; Insel, G.; Pehlivanoglu-Mantas, E.; Ozabali, A.; Tanik, A. Integrated watershed management efforts: Case study from Melen Watershed experiencing interbasin water transfer. Water Sci. Technol. Water Supply 2013, 13, 1272-1280. [CrossRef]

34. Arnold, J.G.; Srinivasan, R.; Muttiah, R.S.; Williams, J.R. Large Area Hydrologic Modeling and Assessment Part I: Model Development. J. Am. Water Resour. Assoc. 1998, 34, 73-89. [CrossRef]

35. Douglas-Mankin, K.R.; Srinivasan, R.; Arnold, J.G. Soil and Water Assessment Tool (SWAT) Model: Current Developments and Applications. Trans. ASABE 2010, 53, 1423-1431. [CrossRef]

36. Arnold, J.G.; Moriasi, D.N.; Gassman, P.W.; Abbaspour, K.C.; White, M.J.; Srinivasan, R.; Santhi, C.; Harmel, R.D.; Van Griensven, A.; VanLiew, M.W.; et al. SWAT: Model Use, Calibration, and Validation. Asabe 2012, 55, 1491-1508. [CrossRef]

37. Neitsch, S.L.; Arnold, J.G.; Kiniry, J.R.; Williams, J.R. Soil and Water Assessment Tool Theoretical Documentation Version 2009; Texas Water Resources Institute Technical Report No. 406; Texas A\&M University System: College Station, TX, USA, 2011.

38. Gassman, P.P.W.; Reyes, M.M.R.; Green, C.C.H.; Arnold, J.J.G. The Soil and Water Assessment Tool: Historical development, applications, and future research directions. Trans. ASAE 2007, 50, 1211-1250. [CrossRef]

39. Food and Agricultural Organization (FAO). The Digital Soil Map of the World and Derived Soil Properties; CD-ROM, Version 3.5; Food and Agriculture Organization of the United Nations, Land and Water Development Division: Rome, Italy, 2003.

40. Hargreaves, G.L.; Hargreaves, G.H.; Riley, J.P. Agricultural Benefits for Senegal River Basin. J. Irrig. Drain. Eng. 1985, 111, 113-124. [CrossRef]

41. Ritchie, J.T. Model for predicting evaporation from a row crop with incomplete cover. Water Resour. Res. 1972, 8, 1204-1213. [CrossRef]

42. USDA. Soil Conservation Service SCS National Engineering Handbook. Section 4, Hydrology. In National Engineering Handbook; USDA: Washington, DC, USA, 1972.

43. Abbaspour, K.C.; Johnson, C.A.; van Genuchten, M.T. Estimating Uncertain Flow and Transport Parameters Using a Sequential Uncertainty Fitting Procedure. Vadose Zone J. 2004, 3, 1340-1352. [CrossRef]

44. Abbaspour, K.C.; Yang, J.; Maximov, I.; Siber, R.; Bogner, K.; Mieleitner, J.; Zobrist, J.; Srinivasan, R. Modelling hydrology and water quality in the pre-alpine/alpine Thur watershed using SWAT. J. Hydrol. 2007, 333, 413-430. [CrossRef]

45. Nash, J.E.; Sutcliffe, J.V. River flow forecasting through conceptual models Part I-A discussion of principles. J. Hydrol. 1970, 10, 282-290. [CrossRef]

46. Gupta, H.V.; Sorooshian, S.; Yapo, P.O. Status of Automatic Calibration for Hydrologic Models: Comparison with Multilevel Expert Calibration. J. Hydrol. Eng. 1999, 4, 135-143. [CrossRef]

47. Rouholahnejad, E.; Abbaspour, K.C.; Vejdani, M.; Srinivasan, R.; Schulin, R.; Lehmann, A. A parallelization framework for calibration of hydrological models. Environ. Model. Softw. 2012, 31, 28-36. [CrossRef]

48. Kamali, B.; Abbaspour, C.K.; Yang, H. Assessing the Uncertainty of Multiple Input Datasets in the Prediction of Water Resource Components. Water 2017, 9. [CrossRef]

49. Aronica, G.T.; Candela, A. Derivation of flood frequency curves in poorly gauged Mediterranean catchments using a simple stochastic hydrological rainfall-runoff model. J. Hydrol. 2007, 347, 132-142. [CrossRef]

50. Morlando, F.; Cimorelli, L.; Cozzolino, L.; Mancini, G.; Pianese, D.; Garofalo, F. Shot noise modeling of daily streamflows: A hybrid spectral- and time-domain calibration approach. Water Resour. Res. 2016, 52, 4730-4744. [CrossRef]

51. Moriasi, D.N.; Arnold, J.G.; Van Liew, M.W.; Bingner, R.L.; Harmel, R.D.; Veith, T.L. Model Evaluation Guidelines for Systematic Quantification of Accuracy in Watershed Simulations. Trans. ASABE 2007, 50, 885-900. [CrossRef]

52. Covelli, C.; Cozzolino, L.; Cimorelli, L.; Della, M.R.; Pianese, D. A model to simulate leakage through joints in water distribution systems. Water Sci. Technol. Water Supply 2015, 15, 852-863. [CrossRef] 
53. Covelli, C.; Cozzolino, L.; Cimorelli, L.; Della Morte, R.; Pianese, D. Optimal Location and Setting of PRVs in WDS for Leakage Minimization. Water Resour. Manag. 2016, 30, 1803-1817. [CrossRef]

54. Covelli, C.; Cimorelli, L.; Cozzolino, L.; Della, M.R.; Pianese, D. Reduction in water losses in water distribution systems using pressure reduction valves. Water Sci. Technol. Water Supply 2016, 16, 1033-1045. [CrossRef] 